\title{
Human Resources Development and Those Left Out: Contribution of Universal Policies
}

\author{
Zoe A. Karanikola, \\ George A. Panagiotopolos, \\ Department of Museology, University of Patras, Greece
}

URL:http://dx.doi.org/10.19044/esj.2020.v16n13p70

\begin{abstract}
This paper focuses on exploring the thematic analysis of the text "Human Development Report" (United Nations, 2016) about the way universal policies can contribute to the development of all left out. This means people that belong to vulnerable groups. What are their characteristics, what are their targets, and how can they be implemented? According to the findings, universalism is the principle of the human development approach, but it is not enough. It is necessary to be translated into practice by identifying and breaking down barriers that exclude certain groups. Some universal policies need to be reoriented, since there are many disparities. Even though human development can be achieved, it does not mean that it can also be sustained. Progress may be slowed or even reversed. In such context, people must get empowered even if policies and the relevant actors fail to deliver. They will get stronger when they demand their rights, raise their voice, and seek to redress one situation. Policies should also be inclusive which involves formulating an employment - led growth strategy. This should be done with emphasis on creating productive and remunerative employment opportunities in sectors where poor people live and work, enhancing inclusion in productive resources, and under taking high-impact multidimensional interventions. The usefulness of this study lies in the fact that it provides useful information about United Nations' efforts and policies to help all people to develop. These efforts and policies can be compared to those of other European and international organizations such as the Council of Europe and the Organization for Economic Co-operation and Development (OECD). This helps in creating larger databases that can multiply and become indicators of relevant actions at both regional and global level.
\end{abstract}

Keywords: Human development, policies, universalism, left out, growth 


\section{Introduction}

Over the past quarter century, there has been impressive progress on many fronts of human development with people rising out of extreme poverty, fewer people being malnourished, more children going to school, and more individuals living longer. However, these gains have not been universally spread, and not all lives have been improved. Millions of people seem to be unable to reach their full potential in life and work. This is mainly because they suffer deprivations in multiple dimensions of human development. Also, there are significant imbalances across countries, ethnic and racial groups, urban and rural areas, and women and men (United Nations, 2016).

According to Selim Jahan (United Nations, 2016,), there are many obstacles preventing people from developing such as social and cognitive constraints, social norms, values and choices, national mechanisms and policies, and the empowerment people exercise not only as individuals but as part of a group as well. Some social norms may be helpful in promoting harmonious coexistence, but others may be discriminatory, prejudicial, and exclusive. Consequently, people left out are on increase not only in the developing countries but in the developed countries as well (United Nations, 2015).

Such groups, as recorded by the United Nations Educational, Scientific, and Cultural Organization (UNESCO) (2015), are adults with a low level of literacy and basic skills, young people who do not attend employment or training program, people seeking to enrich their knowledge and skills, individuals seeking personal development and widening of their knowledge, workers in low-skilled, low-wage or precarious jobs, residents of rural or sparsely populated areas, persons seeking recognition and certification of prior knowledge, socially excluded groups, long-term unemployed, women and middle-aged men, ethnic, linguistic or religious minorities and indigenous people, immigrants and refugees from other countries, adults with disabilities, parents and families, older and retired (senior citizens), and single parent families (Panagiotopoulos \& Karanikola, 2017a, p. 66; UNESCO, 2019).

In such context, a great number of significant texts have been drafted by the European and International Organizations. These organizations provide guidance to member states in order to achieve growth, prosperity, and human development. The European Union, for example, has a long history in shaping policies regarding the development and prosperity of societies. Thus, at the beginning of the 1990s, the European Community stressed the importance of coherence in the effectiveness of development policies. On the other hand, the Treaty of Lisbon states that the Union should take into account the fact that the coherence and cooperation of policies can affect developing countries (Mackie, as cited in Panagiotopoulos \& Karanikola, 2017b). UNESCO, as well, argues that the greatest contemporary challenge facing many countries 
is to meet the deficit in human resources and to improve the quality of policies (UNESCO, 2015). According to Beech (2009), this places the adult at the core of development and promotes the full advancement of human personality in a context of respect and understanding.

\section{Human Development Context}

The development of this chapter begins by referring to a proverb mentioned by Drucker (1956, p. 24) that "no one can possibly eat all the products of their farm alone. Some of those products would have been taken away by birds, passers-by or even would have fallen off during transportation, before it is eaten, shared with family or sold. It is the same about prosperity. Prosperity is essentially shared... It is the outcome of human labour. So the human potential is its biggest driver and final aim."

The United Nations Organization has played an important role in the human development and prosperity approach through its annual Human Development Reports. These reports were initially conceived as an idea by Mahbub ul Haq (Baru, 1998), with the first human development report being published in 1990. Their themes cover majority of topics such as the development of appropriate policies, the empowerment of economy, the protection of fundamental freedoms, culture and cultural identities, the elimination of poverty, and the promotion of health and security. One basic idea and confession is the fact that people and covering their needs is at the centre of interest, since one significant purpose is widening people's choices and the level of their achieved well-being. The issue of values is critical in this approach, and the core principles reported are equity, efficiency, participation, and sustainability (Panagiotopoulos \& Karanikola, 2018).

Development is a process of economic and social transformation. It is a process that increases the reading and the analysis of problems and contributes to individual and social growth in a complex and dynamic way (Escrigas, 2008). On the other hand, human development is a process of enlarging people's choices by building up and widening their capabilities and activating participation in the processes that involve shaping and improving their lives (UNDP, 2016).

Obtaining a variety of right skills is a distinguishing factor of an individual in the era of globalization and the 4th industrial revolution since they are related to economic and social success, helping people to develop their work, and adapting to changing needs (OECD, 2017, p. 32; Riaz, 2016). Basic skills are positively related to better societal and job opportunities (Vorhaus et al., 2011), while gaining higher and more complex transversal skills is of major importance given that they are related to critical thinking, creativity, innovation, effectiveness and efficiency, and decision making (Schuller et al., 2006). 
The basic dimensions of human development and well-being are divided into those that directly improve human abilities (health, longevity, knowledge, resources, and standard of living) and those that create conditions for human development and prosperity (participation in political and community life, environmental sustainability, security, and human rights) (UN, as cited in Panagiotopoulos \& Karanikola, 2017b, p. 95). Emphasis is also placed on autonomy, the ability to deliberate, participate in public debates, and becoming agents in shaping one's life and environment.

Development, though, should be a holistic and broad concept. The basic dimensions are considered to be the socioeconomic, the democratic, and the cultural. Socioeconomic development provides individuals with more autonomy given that they have access to resources that help them improve their income, skills, and facilities (Sen, 1999).

Democracy is the second element of individual choice providing an institutional structure that codifies civil and political freedom (Welzel, Inglehart \& Klingemann, 2001). According to Lipset, Almond and Verba, and Moore (as cited in Menocal, 2011), during the 1960s and 1970s, it was argued that democracy was positively related to high levels of socio-economic development. This implied that development was a precondition for democracy. This modernization approach regarded the development of democracy as a result of the transformation of urbanization, class structure, the development of democratic values, and other cultural agents (Menocal, 2011). However, things changed in the 1980s. Economic development itself is not an adequate condition for the establishment and development of democracy. However, in the 1990s, a new orthodoxy emerged within the international academic circles that argued that democracy is a necessary ingredient to bring development. Among others, healthy democratic governance places emphasis on horizontal and vertical transparency and accountability, inclusive and participatory decision-making processes. The existing literature and research which aims at identifying the causal relationship between development and democracy is still indefinite (Menocal, 2011).

Finally, according to the poet Senghor (1906-2001), culture is the "be all and end all of the development." It is also one of the roots of development not simply in terms of economic growth, but also as a means to achieve a more satisfactory, intellectual, emotional, moral, and spiritual existence (UNESCO, 2001, Article 3). According to Yudice (2003), both development and culture are changing words. However, the relationship between culture and development began to be defended by different experts mainly in the 1980s and 1990s when the international bodies and development cooperation agencies started to promote studies to analyze how cultural factors could have an impact on development (Marana, 2010). 


\section{Methodology of Research}

The aim of this study is to investigate the way universal policies can contribute to the development of all left out through the thematic analysis of the Human Development Report (UNDP, 2016). The research questions examine the characteristics of the policies, their targets, and the way they could be implemented.

The methodological tool of thematic analysis presents data in an analytical and compound way to interpret and comprehend the various dimensions of the subject (Boyatzis, 1998). Simultaneously, it allows the extensive exploration of the deeper structures of the text and includes flexibility, large-scale data, interpretation of subjects based on data, and finally classification (Braun \& Clarke, 2006; Gibbs, 2007).

There are three thematic classes: the basic theme, the organizing theme, and the global theme. The basic theme is related to the simplest characteristics of the text's data and provides very little information about the whole text on its own. In order to achieve a better and clearer understanding of the text's content, it is essential to study the other key issues further. All together, they constitute the second class of themes, and more specifically, the organizing theme. This is a middle-order theme which organizes the main topics in categories of "related" subjects. This particular theme contributes to a better understanding of a more general theme, which connects several organizational issues. Thus, the third theme, the Global Theme, emerges as a super-ordinate theme which contains the basic idea of the text as a whole (Attride-Stirling, 2001).

Particularly, the basic theme of the study is universal policies and development. Subsequently, the organizing themes are characteristics of policies (universal, inclusive, and based on human rights), targets (vulnerable groups, capabilities, accountability, and the right to information), and implementation (cooperation in different levels-local, regional, universal, and financing).

\section{Presentation of Thematic Networks}

The first thematic network refers to the characteristics of the policies. Particularly, these policies are considered to be universal and inclusive. Their main principle is "Freedom for everyone". They are also based on four mutually supporting pillars: formulating an employment -led growth strategy, enhancing financial inclusion in productive resources, investing in human development priorities, and undertaking high-impact multidimensional interventions (UNDP, 2016, p. 11). However, policies have to be empowered by upholding human rights (such as bodily integrity, free association, political participation) through well-established domestic mechanisms and international action (UNDP, 2016, p. 16). Human development and human 
rights are closely related, while the best way to secure fundamental rights could be to consider rights in terms of capabilities. To secure a right is to enable people to do something that they have reason to value, especially in the cases where some rights are recognized but they are not implemented or available in practice. Consequently, some women may have the right to vote but be threatened with violence if they leave the house (UNDP 2016, p. 86).

One of the main challenges of universalism is reaching out to those who experience the most extreme deprivations and those who are socially marginalized and excluded (UNDP 2016, p. 52). This means that there are many barriers to universalism. These barriers include narrow self-identities, weak bargaining power, intolerance and exclusion, and elite capture of institutions. Narrow self - identities involve nationalism and identity policies; intolerance and exclusion refer to discriminatory laws, social norms, and violence; weak bargaining power is about inequality and lack of voice; while elite capture of institutions refers to the lack of pluralism (UNDP 2016, pp. 79-80). According to the text, these barriers could be broken down through shocks, disasters, crises, political shifts, spread of technologies, globalization of information, business and social networks. All these can unite, empower, and motivate people to push for change through intergovernmental agreements (United Nations, 2016, p. 80).

According to the second thematic network, the targets of the policies are enhancing opportunities for women, addressing lifecycle capabilities, ensuring access to justice, promoting inclusion facilitated by technology and social media, ensuring accountability, and stabilizing the global economy (UNDP, 2016, p. 17). Accountability is positively related to the fact that human development reaches everyone, especially in protecting the rights of those excluded. On the other hand, information and communication technology is a major instrument for ensuring accountability of social institutions. The right to information requires the freedom to use that information to form public opinions, call governments to account, participate in decision making, and exercise the right to freedom of expression (UNDP, 2016, p. 17).

The third thematic network is about the implementation of these policies. Cooperation in local, regional, global levels, right financing, promoting the right skills, empowering human rights, and developing the right domestic and national policies can contribute towards this direction. In addition, national policies should use affirmative action, promote human development for marginalized groups, uphold human rights, ensure access to justice, promote inclusion, ensure accountability, mobilize resources for human development, address lifecycle capabilities, enhance opportunities for everyone, and pursue inclusive growth (United Nations, 2016, pp. 80-91). 


\section{Conclusion}

According to the text, universalism and inclusion is the key principle of the human development approach. This is consistent with the spirit of many other official texts of the international organizations (European Commission, 2015; OECD, 2013; United Nations Educational, Scientific and Cultural Organization, 2016). Universalism is necessary to be translated into practice by breaking down barriers excluding certain groups. In such context, some universal policies need to be reoriented, since there are many disparities. It should also be taken into consideration that human development is not permanent and sustained. Progress could also be reversed. Therefore, individuals are those who should be empowered through lifelong learning, training, and education. Education policies should address learning in a wide range of economic, political, social, cultural, technological, and environmental sectors.

As far as the inclusive policies are concerned, they should provide equitable access to opportunities and strategies without discrimination. In this way, they contribute to the protection of fundamental human rights such as respect for diversity, empowerment of all vulnerable social groups, solidarity and social justice, and cohesion.

Last but not the least, the evaluation of the implementation of these policies is crucial. Towards this direction, many agents could cooperate including agents from both private and public sector such as ministers, businessmen, governmental organizations, research institutes, civil society organizations, trade unions, etc.

\section{References:}

1. Attride Stirling, J. (2001). "Thematic Networks: an Analytic Tool for Qualitative Research". Qualitative Research Copyright, I (3), 385405. https://doi.org/10.1177/146879410100100307

2. Beech, J. (2009). "Who is strolling through the global garden? International agencies and educational transfer". In R. Cowen, \& A. Kazamias (Eds), International Handbook of Comparative Education (341-357). Dordrecht: Springer. https://doi.org/10.1007/978-1-40206403-6_22

3. Boyatzis, R. (1998). Transforming Qualitative Information: Thematic Analysis and Code Development. Thousand Oaks, CA: SAGE Publications Ltd.

4. Braun, V. \& Clarke, V. (2006). "Using thematic analysis in psychology". Qualitative Research in Psychology, 3, 77-101. https://doi.org/10.1191/1478088706qp063oa 
5. Drucker, P. (1956). "The manager of tomorrow". In H. C. Thole, \& C. C. Gibbons (Eds), Business Action in a Changing World (17-24). Chicago: Public Administration Service.

6. Escrigas, C. (2008). Forward in GUNI. Higher Education in the World 3. London: Palgrave Mcmillan.

7. European Commission (2015). An in-depth analysis of adult learning policies and their effectiveness in Europe. Luxembourg: Publications Office of the EU.

8. https://ec.europa.eu/epale/sites/epale/files/all_indepth_analysis_of_ad ult_learning_policies_and_their_effectiveness_in_europe_12.11.2015 _pdf.pdf.

9. Gibbs, G. (2007). Thematic Coding and Categorizing. Analyzing Qualitative Data. Thousand Oaks, CA: SAGE Publications Ltd.

10. Baru, S. (1998). "Mahbub ul Haq and Human Development: A tribute". Economic and Political Weekly, 33(35), 2275-2279.

11. Mackie, J. (2007). Evaluation of the EU Institutions \& Member States' Mechanisms for Promoting Policy Coherence for Development, Study for the Evaluation Services of the Ministries of Foreign Affairs of France and Belgium, the Federal Ministry of Development Cooperation Germany and DG Europe Aid, European Commission, The Triple $C$ Evaluations (7). Amsterdam: Aksant Academic Publishers. http://ecdpm.org/publications/evaluation-study-eumember-states-mechanisms-pcd/

12. Marana, M. (2010). Culture and Development. Evolution and Prospects. Center of the Basque Country: UNESCO.

13. Menocal, A.R. (2011). Analyzing the relationship between democracy and development: Defining basic concepts and assessing key linkages. https://www.researchgate.net

14. Organization for Economic Co-operation and Development (2013). Skills Outlook 2013: First results from the Survey of Adult Skills. Paris: OECD. http://skills.oecd.org/OECD_Skills_Outlook_2013.pdf

15. Organization for Economic Co-operation and Development (2017). OECD Skills outlook 2017: Skills and global value chains. Paris: OECD. http://dx.doi.org/10.1787/9789264273351-en

16. Panagiotopoulos, G. \& Karanikola, Z. (2017a). "Labor Market and Development: UNESCO Research Data on Human Resource Training". European Journal of Training and Development Studies, 4 (3), 62-72.

17. Panagiotopoulos, G. \& Karanikola, Z. (2017b). "Skills: A Pathway to Employability and Prosperity. European Commission Policies". International Journal of Education, Learning and Development, 5 (10), 92-101. 
18. Panagiotopoulos, G. \& Karanikola, Z. (2018). Occupational and Professional Development: OECD Policy Analysis on Skills. International Journal of Developing and Emerging Economies, 6 (4), 1-10.

19. Riaz, M. (2016). "The importance of skills". The Express Tribune, 04/ 25/2016.

20. Schuler, R. \& Jackson, S. (2006). Human Resources Management: Positioning for the 21 st century. NY: West Publishing.

21. Sen, A. (1999). Development as Freedom. Oxford: Oxford University Press.

22. United Nations Educational, Scientific, and Cultural Organization (2001). UNESCO Universal Declaration on Cultural Diversity. http://www.unesco.org/new/en/social-and-humansciences/themes/international-migration/glossary/cultural-diversity/

23. United Nations Educational, Scientific, and Cultural Organization (2015). Recommendation on Adult Learning and Education. http://unesdoc.unesco.org/images/0024/002451/245119M.pdf

24. UNESCO, GRALE III (2016). 3rd Global Report on Adult Learning and Education. The Impact of Adult Learning and Education on Health and Well-Being; Employment and the Labor Market; and Social, Civic and Community Life: UNESCO Institute for Lifelong Learning. http://uil.unesco.org/adult-education/global-report/third-globalreport-adult-learning-and-education-grale-3

25. UNESCO, GRALE 4 (2019). 4th Global Report on Adult Learning and Education. Leave no one behind: Participation, Equity and Inclusion.

26. https://uil.unesco.org/adult-education/global-report

27. United Nations General Assembly (2000). United Nations Millennium Declaration, Resolution A/RES/55/2 of 8 September 2000. http://www.un.org/millennium/declaration/ares552e.htm

28. United Nations General Assembly (2015). Human Development Report 2015: Work for Human Development. NY: United Nations Development Program. http:// hdr.undp.org/sites/default/files/2015_human_development_report.pdf

29. United Nations Development Program (2016). Human Development Report. Human Development for Everyone. UNDP.

30. https://www.google.com/search?q=Human+Development+Report+20 16+Human+Development+for+Everyone\&rlz=1C1JZAP_elGR815G R815\&oq=Human+Development+Report+2016+Human+Developme $\mathrm{nt}+$ for+Everyone \&aqs=chrome..69i57j0j69i60.1179j0j8\&sourceid=c hrome\&ie $=$ UTF-8

31. Vorhaus, J., Litster, J., Frearson, M., \& Johnson, S. (2011). Review of research and evaluation on improving adult literacy and numeracy 
skills. London: UK Government Department for business, Innovation and Skills.

32. https://assets.publishing.service.gov.uk/government/uploads/system/u ploads/attachment_data/file/32356/11-1418-review-research-onimproving-adult-skills.pdf

33. Welzel, C., Inglehart, R., \& Klingemann, H.D. (2001). Human Development as a General Theory of Social Change: A multi-level and Cross-cultural Perspective, WZB Discussion Paper. FS III 01-201. Berlin: Wissenschaftszentrum Berlin für Sozialforschung.

34. Yudice, G. (2004). The Expediency of Culture. Duke University Press. 